\title{
Nasıl Mantılkçı Oldum ya da Olamadım?
}

\section{How Did I (or Couldn't I) Become a Logician?}

\author{
A. Kadir Çüçen ${ }^{1}$
}

'Prof. Dr., Uludağ Üniversitesi, Fen-Edebiyat Fakültesi, Felsefe Bölümü, Bursa, Türkiye

ORCID: A.K.Ç. 0000-0001-8092-1472

\section{Sorumlu yazar/Corresponding author: \\ A. Kadir Çüçen, \\ Uludağ Üniversitesi, Fen-Edebiyat Fakültesi,}

Felsefe Bölümü, Bursa, Türkiye

E-posta/E-mail: kadir@uludag.edu.tr

Başvuru/Submitted: 04.11.2019

Kabul/Accepted: 08.12.2019

\section{Atıf/Citation:}

Cücen, A. Kadir. (2019). “Nasıl Mantıkçı Oldum ya da Olamadım?" Felsefe Arkivi-Archives of Philosophy, 51: 363-366.

https://doi.org/10.26650/arcp2019-5130

\section{ÖZET}

Bu denemenin amacı, mantık serüvenimin aşamalarını ortaya koyarak nasıl mantık alanına zaman zaman dahil olduğumu nasıl dahil olamadığımı itiraf etmektir. Bu nedenle lisans yıllarımdan başlayarak mantık ile olan ilk tanışmamı ve daha sonraki süreçleri de aldım. Lisans sonrası süreçte ve öğretim hayatında da devam eden mantıkla olan ilgim hiç azalmadı. Dil ve Tarih Coğrafya Fakültesi ile başlayan mantık öğrenimim, Orta Doğu Teknik Üniversitesi ve Daha sonra University of Pittsburgh'ta devam etti. Doktora sonrası verdiğim dersler ve yaptığım mantık çalışmaları ile alana zaman zaman katkı yaptım, ama yine de bu alandaki yetkinliğim her zaman benim için yeterli olmadı. Bu nedenle kendime hep sordum: Ne kadar mantıkçıyım? Bir tür kısa otobiyografi türünde olan bu deneme, aynı zamanda bana katkı yapan mantıkçıları da burada saygı ile anmamı sağlamaktadır. Ülkemizdeki mantık çalışmalarının son 40 yılına da ışık tutacak bu deneme, mantık çalışmalarının da geldiği seviyeyi göstermektedir. Şu an Mantık Derneği çatısı altında, çalışmaların devam etmesi, Ülkemizdeki mantık çalışmalarını olumlu yönde etkileyecektir.

Anahtar Kelimeler: Mantık, mantık derneği, Dursun Murat Çüçen, Necati Öner, Teo Grünberg, Şafak Ural ve Nuel Belnap

\section{ABSTRACT}

Displaying the stages of my expedition in logic, the purpose of this essay is to admit how I have been involved in the field of logic from time to time -and how, sometimes, I have not. Therefore, starting from my undergraduate years, I shared my first acquaintance with logic and the following processes. My interest in logic has continued after my graduation and throughout my teaching life, and has never decreased. My education in logic started at the Faculty of Languages, History and Geography, and continued at the Middle East Technical University and then at the University of Pittsburgh. I have contributed to the field of logic with the courses that I instructed after finishing my $\mathrm{PhD}$, and along with my studies on logic, yet my competence in this field has not always satisfied me. That is why I have always asked myself: To what degree I am a logician? This essay, which is a kind of short 
autobiography, also allows me to respectfully acknowledge the logicians who contributed to me. This essay, which also sheds light on the past 40 years of the logic studies in our country, demonstrates the current level of logic studies. The continuation of the studies under the umbrella of the Logic Association would provide a positive impact on the logic studies in our country.

Keywords: Logic, logic association, Dursun Murat Çüçen, Necati Öner, Teo Grünberg, Şafak Ural and Nuel Belnap

1981 yılında felsefe öğrenimime başladığım Dil ve Tarih-Coğrafya Fakültesi, Sistematik Felsefe ve Mantık Anabilim Dalında Prof. Dr. Necati Öner hocamızın verdiği Klasik Mantık dersi ile mantık alanıyla tanıştım. Prof. Öner, kendi yazdığı Klasik Mantık kitabıyla sınıfa gelir ve kürsüye oturduktan hemen sonra çok ciddi bir biçimde derse başlardı. Önce tüm sınıf olarak hocayı anlamakta zorlanıyorduk; çünkü mantık terim ve kavram hazinemiz azdı ve üstelik hocamız kendi çağının terim ve kavramlarını kullanıyordu. Prof. Öner hocamız dersini çok iyi anlatırdı. O, klasik mantık alanında 20. yüzyıl Türkiye’sinin en iyilerinden biriydi. Bütün yaşamını klasik mantık çalışmalarına ve öğrenci yetiştirmeye adayan bir akademisyen olarak Prof. Öner'den hepimiz çok şey öğrendik. Nurlar için uyusun. Bir konferansta şöyle demişti: "Benim adım George ya da Michael olsaydı, Dünya beni tanırdı, ama bulunduğum coğrafya ve dini inanç nedeniyle kendimizi tanıtmakta çok zorlanıyoruz. Yapmamız gereken, onlara kendimizi çalışmalarımızla tanıtmaktır.” Bu düşünce doğrultusunda hocamız çok sayıda mantıkçı yetiştirdi ve her birinden çalışmalarını her türlü aracı kullanarak tanıtmalarını istedi. Öyle zannediyorum ki hocanın bu isteği, mantık çalıştayları serisi ile önce ulusal, sonrada uluslararası olma yoluna girdi.

1982 yılında artık ikinci sınıftaydım ve Dr. Dursun Murat Çüçen' in ${ }^{1}$ modern mantık derslerini almaya başladım. Her yıl iki dönem olmak üzere altı dönem hocamızdan değişik mantık dersleri aldım. Bunlar; çözümleyici çizelge, indirgeyici çizelge ${ }^{2}, 0-1$ yöntemi ${ }^{3}$, çok değerli mantık, tartışma mantığı, ödev mantığı, doğal türetim yöntemi, Beth çizelgesi, Polonya notasyonu ile 3 ve 4 değerli mantıklar, önermeler ve yüklemler mantığı gibi bir çok mantık konu ve yöntemini bizlere anlattı. Derslerinde öz Türkçe konuşmaya özen gösterdiği gibi, mantık terimlerini de olabildiğince öz Türkçeden karşılık bularak dile getirmeye çalışırdı. Ayrıca klasik mantığın tasımlarını, Polonya notasyonu ve kendisinin eklediği mantık simgeleriyle doğal türetim yöntemini kullanarak gösterme ve denetlemeyi başarmıştı. Dursun Murat Çüçen, ülkesini, Cumhuriyetini ve kurucu lideri Mustafa Kemal Atatürk'ü seven bir vatansever olarak, Atatürk'ün "Ya istiklal ya ölüm” deyişini, atasözlerindeki mantıksal argümantasyonu, Nasreddin Hocanın fıkralarındaki çıkarımları, Türk romanları ve hikâyelerindeki mantık çıkarımlarını araştırıp bulmayı ve denetlemesini yapmayı kendisine görev edinmişti. Öğrencilerine verdiği bitirme çalışmaları da genellikle mantığın yaşamdaki karşılığı ile ilgili konulardı. Hocamız nur içinde uyusun.

1 Dursun hocamızın babası ile benim babam amca çocuklarıdır ve kendisi aynı zamanda eşimin amcasıdır.

2 Hocamızın bir derste kendisine sorulan soru üzerine çözümleyici çizelgeye karşılık geliştirdiği bir denetleme yöntemidir. Bir öğrenci şu soruyu sordu: "Şu ana kadar yaptığımız geçerlilik ve eşdeğerlilik denetlemelerinin hepsi dolaylı olarak geçersizliğini ya da eşdeğer olmadığını göstermeyi amaçlamaktadır. Niçin doğrudan geçerli ya da eşdeğer olduğunu denetlemiyoruz ?" Hocamız bunun üzerine bir yıl sonra kendi geliştirdiği ve doğrudan denetleme yapan İndirgeyici Çizelge Yöntemini derslerde anlatmaya başladı. Daha sonra hem Türkçe hem de yurt dışı yayınları ile yöntemi bilim dünyasına tanıttı.

3 Dursun Murat Çüçen 0-1 Yöntemini Venn Çizitlerine alternatif bir yöntem olarak geliştirdi. Venn Çizitleri, geometrinin şekillerini kullanırken, 0-1 Yöntemi matematiğin sayıları ve işlemlerini kullanmaktadır. 
Lisans 3. Sınıfta ODTÜ'den dersimize gelen Prof. Dr. Ahmet İnam hocayla tanıştım. Hocamız yeni doçent olmuş, istekli, bilgili ama o zamanlar utangaç bir genç akademisyendi. 'Bilgi Teorisi ve Mantık' adı altında bir ders vermekteydi. Hocamızla ikinci sefer ODTÜ'de başlayıp bitiremediğim yüksek lisans programında karşılaştım. Bu defa 'set teorisi' anlatmaktaydı. Bir teneffüste arkadaşlara hocamızın derste yarım bıraktığı teneffüs sonrası devam edeceği bir geçerlilik denetlemesinin çözümlemesini yaparken, hoca sınıfa erken geldi ve benim soruyu çözdüğümü görünce şöyle bir espri yapmıştı: "Artık dersin kalan kısmını Kadir devam edecek." Ben hem utanmış hem de kalan kısmını bilmediğimi söylemiştim.

1986-1987 öğretim yılının Güz dönemi ODTÜ Felsefe Bölümünde yüksek lisansa başladığımda Prof. Dr. Teo Grünberg ve dersi onunla birlikte yürüten Suvar Kösearif'le tanışma ve ders alma fırsatı buldum. Özellikle Suvar Hocamızın kendi hocası da olan Teo Hoca ile olan tartışması ve dersi karşılıklı diyalog biçiminde işlemesi bizi oldukça şaşırtmıştı. O güne kadar bir dersi iki hoca birlikte işlememişti. Ayrıca biri hoca, diğeri öğrencisi olan iki akademisyen karşılıklı birbirleriyle konuşuyorlardı, hatta bizim onları dinlediğimiz ya da orada olduğumuzu bile hissetmiyorlardı. Karşılıklı tartışmaya ve gerekçelerle sorunu savunmaya çalışmaları bize çok iyi bir örnek oluşturmaktaydı.

1986-87 öğretim yılında Dil ve Tarih -Coğrafya Fakültesi Felsefe Bölümünde mantık alanında yetiştirilmek üzere açılan araştırma görevlisi sınavına girmemi ve yetişmemi o dönemin hocaları talep etmişti. Ne yazık ki sınavda bölüm içi dengelerin değişmesi sonucu başarısız olduğum söylendi. Büyük bir hayal kırıklığı içinde tam mantık alanından hatta felsefeden vazgeçmek üzereydim ki günün birinde bir öğrenci evinde sabah kahvaltı yaparken, masaya örtü bezi olarak serdiğimiz bir önceki güne ait gazetede Uludağ Üniversitesi İlahiyat Fakültesi'nin mantık alanında ders verecek öğretim görevlisi ilanına rastladım. Aynı gün başvuru evraklarımı yolladım. İki ya da üç ay sonra babam aradı ve beni Bursa'dan sınava beklediklerini söyledi. Şaşırmıştım, çünkü daha önce verilen söz aklıma geliyordu ve ben sınavda başarısız olma durumunu tekrar yaşamak istemiyordum. Ama kendime ve bilgime olan güvenim nedeniyle sınava gittim. Üç kişilik komisyon beni karşılarına aldılar ve yaklaşık iki saat sözlü bir mülakat yaptılar. Diğer başvuran kişi gelmediği için bütün zamanı bana ayırdılar. Yıllar sonra karşılaşıp ismini öğrendiğim Prof. Dr. Hüseyin Aydın sınav komisyonu başkanıydı ve en çok soru soran hocaydı. Çalışma deneyimim olmadığı için o göreve atanamadım ama Hüseyin hocamın sınav sonunda bana verdiği hayat dersi, alanda iyi olduğumu ve daha da iyi olabileceğimi söylemesi her şeyi değiştirdi. Dil ve Tarih-Coğrafya Fakültesindeki hayal kırıklığı artık gitmişti. Bir müddet sonra Milli Eğitim Bakanlığı ve YÖK işbirliği ile açılan Yurtdışı Doktora Bursu sınavına girmem ve kazanmam hayatımdaki diğer bir dönüm noktasıydı.

1989-90 öğretim yılında yurt dışında doktora yaparken tekrar mantık dersi almak istemem, bir başka mantıkçıyla yolumu kesiştirdi. Pittsburgh Üniversitesi Felsefe Bölümü’nde görev yapan Prof. Dr. Nuel Belnap’tan mantık dersi almaya başladım. Hocamızın alanında ünlü olduğunu dersi almaya başlayınca öğrendim. Kendisine çok şey borçluyum. 
Ne yazık ki mantık dersi alma serüvenim burada bitiyor. Çünkü doktoramı 20. yy. filozoflarından Martin Heidegger üzerinde yaptım ve hiç de mantıkla ilgisi olmayan bir problem üzerinde tez yazdım: "Varlık problemi". Böylece mantıkçı olma serüveni sadece gerçekten iyi mantıkçılardan ders almam ve onları tanıma fırsatı ile sonlandı.

1994-95 öğretim yılında Uludağ Üniversitesi Felsefe Bölümü’nde göreve başladığımda mantık derslerini veren hoca görevi bırakıp istifa etmişti. Bana "bu dersi verir misiniz?" diye sorulunca tekrar mantıkla yollarım kesişti. O yıllar rahmetli Prof. Dr. Arda Denkel hocamız bölümde ders veriyordu. Onun cesaretlendirmesi ve aldığım mantık dersleri, bu işi lisans düzeyinde yapabileceğim güvenini sağladı. Böylece mantık serüveni tekrar başladı. Uzun süre tüm mantık derslerini verirken, ODTÜ'den doktorasına alıp bölüme katılan Prof. Dr. Zekiye Kutlusoy, modern mantık derslerini benden devraldı. Ben de klasik mantık derslerini vermeye sürdürdüm. Fakat ne zaman bir mantık hocası bulsam hemen dersleri devrediyordum. Bu arada lisanstan arkadaşım olan ve daha sonra öğrencim olan Dr. Öğr. Üyesi Caner Çiçekdağı mantık derslerini vermeye başladı. Caner hoca ayrılınca yine bana kaldı dersler. Sonra, Teo Grünberg hocayı tanıyıp, ODTÜ'de mantık okuyan Doç. Dr. Aytekin Özel, Uludağ Üniversitesi İlahiyat Fakültesinde göreve başlayınca, hocamız tekrar mantık derslerini vermeye başladı. Böylece bir joker gibi mantık dersleri veren hoca oldum ama “acaba mantıkçı olabildim mi?" diye hep kendime sordum.

Mantık derslerini verme sürecinde lisans düzeyine hitap edecek 'Mantık' ve 'Klasik Mantık' adlı iki kitap yazdım. Hiç dersini alamadığım ama kendisini yapıtlarından tanıdığım ve sonra da tanışıp dost olduğum, ülkemizin son zamanlarda yetiştirdiği en iyi mantıkçılardan biri olan, İstanbul Üniversitesi Felsefe Bölümü Mantık Ana Bilim Dalını da kuran Prof. Dr. Şafak Ural hocamızla yolumuz "Mantık Çalıştayları" ile bir kez daha kesişti. İlk Çalıştayı Büyük Ada'da küçük bir grupla yapmaya başladığımız "Mantık Çalıştayları”nın bir tanesini de 2015 yılında Bursa'da gerçekleştirdik. Dursun Murat Çüçen anısına yaptığımız "V. Mantık Çalıştayı"nın bildiri kitabı da Sentez Yayıncılıktan basıldı. Yalnızca bir mantık çalıştayı hariç hepsine birer bildiri sunarak katıldım. Bununla birlikte, 'Mantık Derneği' kurucu üyesi ve Bursa İl temsilcisi olarak mantık alanına hizmet etmeye devam etmekteyim.

"Neden ve nasıl mantıkçı oldum ya da olamadım?” sorusu sanırım yeterince yanıtlandı. Kendi çapımda Türkiye'deki mantık çalışmalarına ve öğretimine katkı yaptım ama doktora tezimin çağdaş felsefe üzerine olması nedeniyle, sanırım mantığın içine bu alana gerçekten emek verenler kadar giremedim. Fakat son zamanlarda mantık alanına ilginin artması, özellikle Mantık Çalıştayı'na olan ilginin çoğalması çok sevindiricidir.

Genç arkadaşlara önerim, Türkçeyi kullanarak mantık terim ve kavramlarının karşılığını oluşturmak, eğer yapabilirlerse, Türkçe mantık terimleri üretmeleridir. Böylece düşünme, gücünü ana dilden alarak, daha ileri bir düzeye erişecektir. Mantık önerme ve çıkarımlarının, edebiyat alanında ve halk söyleminde nasıl kullanıldığının tespiti, mantıkçıların yerine getirmesi gereken bir görevdir. Türkçede ödev, emir, varlık, izin, yasak, söz verme, vb gibi eklemlerle kurulan cümlelerin mantıktaki karşılıklarının incelenmesi gerekmektedir. Yapay zeka, puslu mantık, olasılıklı mantık, kiplik mantığı, ödev mantığı ve varlık mantığı alanlarında çalışmaların çoğalması, tümüyle genç mantıkçıların çabalarına bağlıdır.

Kasım 2019, Bursa 